arrange general meetings where scientific subjects were dealt with in a popular manner. The fact had to be remembered that many of the members came to the meetings after working hard all day, and with their brains more or less exhausted and in need of recreation.

Mr. Rudler also dealt with the craze for athleticism, which tended to lessen the ranks of the local societies and even of the British Association itself. He said that a party on a field excursion would get more physical benefit than a crowd of spectators watching competitions between professional athletes. "He contended that the taste for "sport" of to-day was only a part of a large subject, the excessive love of pleasure. He said that different people had different ideas with regard to recreation, but that those who turned to natural history were exceptionally wise in their choice. Parents, and especially ladies, would, he suggested, do well to join a natural history society, if only as an example for the young, and to introduce them to a healthy atmosphere. Now that nature-study was successfully edging its way into our schools, there should be a fine crop of young naturalists in the making, and Mr. Rudler told the societies not to wait for the students to grow up, but to found branches for junior members.

After saying a word as to the secondary place that the results of the camera and the magic lantern should take in popuiar lectures, Mr. Rudler passed on to speak of the scientific work done by Maidstone men in the past, and to congratulate the town upon its museum.

On the morning of June Io business was transacted, and officers and committee elected "For the Photographic Record and Survey of Kent," after a report of the work of the provisional committee had been read by $\mathrm{Mr}$. $\mathrm{H}$. Snowden Ward, who had acted as organising secretary.

Mr. F. J. Bennett, in a short paper, pointed out that the Kentish megaliths, like those in Wiltshire, follow lines which run from north to south, and this is also true in the case of earthworks and churches. A paper on the Lepidoptera of mid-Kent, by Captain Saville G. Reid, was taken as read, and the meeting concluded with some excellent suggestions by $\mathrm{Mr}$. Bennett with regard to the utilisation of the twenty-five inch Ordnance maps by farmers. On these a plan of the drainage, the arrangements for which are often completely forgotten, could be entered, together with details of the work carried on from year to year. Mr. Bennett urged that such work should be secured by legislation, and the suggestion met with cordial approval. On the afternoon of June io there were two excursions; the first-geological and archæologicalwas to Aylesford, under the leadership of $\mathrm{Mr}$. Whitaker and Mr. W. H. Benstead. The second was of a botanical and entomological character to the North Downs, under the leadership of Prof. Boulger, Captain Reid, and Mr. Elgar. In the evening the Mayor and Mayoress (Alderman and Mrs. Morling) held a reception in the Museum, Art Gallery and Technical Schools, which adjoin one another in a very convenient way. Afterwards the visitors had an opportunity of examining the Congress Museum, which consisted of specimens sent by members of affiliated societies, and arranged by Mr. E. W. Swanton. There were also on view nature-study exhibits from Kent schools to illustrate the paper to be read on the following morning. During the evening Mr. A. B. Harding read a paper on "Ice Streams and Ice Caves," and Mr. Paul Matthews described the possibilities of an artificial language, and gave an explanation of that which is known as "Esperanto."

On June in the election of officers took place. Prof. Flinders Petrie was elected president, and Dr. Abbott, to whom the union owes its origin, exchanged his office of honorary secretary with the Rev. R. Ashington Bullen for that of treasurer, which the latter occupied. The two vacancies on the council were filled with Miss Lawrence, of Reigate, and Mr. Wilfred Mark Webb.

When the last paper, which was on "The Teaching of Nature-study," was read by Mr. Wilfred Mark Webb, a number of teachers and pupil teachers were present through the efforts of the Kent County Education Committee and the local committee of the congress. Considerable discussion took place afterwards. Sir Henry Howorth supported the aim that the pupil should be made to ask why and to find out the answer for himself, and dwelt for some time on the advisability of studying animals in captivity.
Prof. Boulger thought that nature-study should, in the case of young children, be correlated with poetry. Mr. Tutt pointed out the difficulties that occur in town schools, and urged the claims of more formal work than had been outlined, which savoured somewhat of science teaching. Mr. J. B. Groom, of St. Paul's Schools, Maidstone, who has made a speciality of rambles, begged the young teachers present to follow informal lines rather than those advocated by Mr. Tutt.

The number of societies now affiliated is forty-three, with upwards of five thousand members, while the funds of the union are in a satisfactory condition, and an invitation has been accepted to visit Reigate during 1905.

\section{EDUCATIONAL CONFERENCE AT THE HORTICULTURAL EXHIBITION.}

$\mathrm{O}^{\mathrm{N}}$ June 7 a conference was held at the Royal Botanic Gardens, Regent's Park, in connection with the educational section of the Horticultural Exhibition, which was open during the whole of last week.

Sir William J. Collins, chairman of the Education Committee of the London County Council, and president of the section, took the chair, and Mr. F. W. Verney read a paper on "Allotment Gardens and Working Men." In the course of this a good deal of stress was laid upon the need for teaching which would prepare country boys to work on the land, and a scheme for their education was mapped out. It seems to be generally recognised that if a boy is ever to do much good on a farm he must become acquainted with its working at an early age, and the compromise desired by Mr. Verney that a boy should be allowed to do some practical work on a farm before his school days are over would not only satisfy practical requirements, but would also probably keep the pupils under the influence of the schoolmaster for a longer period than is at present the case.

Miss Lilian Clark afterwards read a paper upon "Direct Methods of Studying Nature," such as are employed at the James Allen School for Girls, Dulwich. The papers which Miss Clark has read in the past at various science conferences have made us familiar with her work in garden and classroom, where real plants and not books are studied. It is interesting to be able to chronicle that a special room, which is a combination of laboratory and greenhouse, has been built as an aid to the experiments and observations which she directs.

Later in the morning Sir George Kekewich, who is president of the School Nature Study Union, gave an address on "Nature-study and its Cognate Educational Subjects." $\mathrm{He}$ made a special point of nature-study as a part of general education, saying that he would like to see it taught in every school in this country. The kind of training outlined was that now generally recognised as being really nature-study, and as Sir George Kekewich is one of those who think that the work, to be done properly, should be carried on out of doors, he spoke of the great difficulties which must exist in the case of most town schools. These difficulties would be all the greater if teachers felt, as Sir George Kekewich seems to do, that to keep animals in captivity (Sir George afterwards excepted canaries) is calculated to teach cruelty.

In the discussion the speakers were practically unanimous in disagreeing with the contention last alluded to. $\mathrm{Mr}$. Hedger Wallace (honorary secretary of the section), Miss Kate Hall, and Miss Von Wyss were among those who thought that many animals could be properly studied "under control." The present writer expressed his opinion that as children see plenty of cruelty in their everyday life, it would be advisable to teach them kindness by keeping pets, and that if this were not done in nature-study, a great power for good would be thrown away.

Sir William Collins summed up nature-study; he said that it was not a new subject, though its recognition and the enthusiasm for it were new, and he emphasised the fact alluded to by Sir George Kekewich that it was not science teaching.

The opinion expressed by Sir George Kekewich that nature-study would not stay the rural exodus, and that its far-reaching effects would not be felt until other means

NO. I807, VOL. 70] 
had been taken to stem the tide of emigration into towns, was not endorsed by the Rev. Claud Hinscliff, who, from his experience in Derbyshire, had come to a different conclusion.

Mr. J. Weathers, instructor in horticulture to the Middlesex County Council, read a paper on "Horticultural Teaching among Adults." His remarks referred mainly to the practical side, though in touching upon laboratory. work he said that he believed in practice first and theory afterwards. Mr. Weathers also considered the question of allotments, and in the discussion which followed, Earl Carrington tellingly described from his own experience the advantages derived from small holdings by the tenants, by the landlords, and by the country at large. Mr. J. Martin White thought that a little theory was sometimes good to begin upon, and he pointed out the need for more attention to be paid in general to methods of cutting and keeping flowers for decorative purposes.

Mr. E. Caesar, headmaster of Hale School, Farnham, outlined in a paper "On School Gardens" the scheme of the Surrey County Council, and the work which had resulted in his own school holding premier place for four years running.

The last paper, on "School Nature-study," was by Miss Violet James, of Heidelberg College, Ealing. Miss James has tested the value of nature work, and not only has she discovered its powers for good, but has recognised the opportunities that exist for evil if the teacher pursues wrong lines.

Wilfred Mark WebB.

\section{UNIVERSITY AND EDUCATIONAL}

\section{INTELLIGENCE.}

OXFORD.-In convocation on June 2 the honorary degree of M.A. was conferred on Mr. F. A. Bellamy, first assistant at the university observatory.

Junior Scientific Club :- The ninth Robert Boyle lecture was delivered on June 3 by Prof. J. J. Thomson, F.R.S., on the subject of "The Structure of the Atom." On June io Dr. G. Mann, New College, read a paper on "The Importance of Salts in our Economy.'

CAMBridge.-In the mathematical tripos, part i., the senior wrangler is Mr. A. S. Eddington, Trinity. The second place is taken by Mr. G. R. Blanco-White, Trinity, and the third by Mr. F. J. M. Stratton, Caius.

Prof. J. W. Gregory, F.R.S., professor of geology in the University of Melbourne, has been appointed to the chair of geology in the University of Glasgow.

THE following honorary degrees were conferred by Dublin University on June I I :-Doctors in Science, Prof. J. Dewar, Prof. J. H. van 't Hoff, Prof. Felix Klein, Major Ronald Ross, C.B., Mr. J. J. H. Teall, F.R.S., and Prof. W. H. Thompson.

Dr. T. MARTin Lowry has been appointed lecturer in science at the Westminster Training College. Dr. Lowry will have charge of the whole of the science work of the college, and will also supervise the scientific instruction at the Southlands Training College.

MR. R. BLAIR, secretary in respect of technical instruction for the Department of Agriculture and Technical Instruction in Ireland, has been appointed executive officer for the performance of duties in connection with the administration of the Education Acts by the London Education Committee.

Mr. John D. Rockefeller has, says Science, given to the Case School of Applied Science 40,00ol. to be used for building and equipping laboratories for physics and mining engineering. Yale University will receive as residuary legatee more than $50,000 l$. from the estate of the late Mr. W. B. Ross, of New York City. The will of the late Prof. Maxwell Sommerville provides 40ool. for the preservation and care of the collection of engraved gems and ethnological collections given by him to the University of Pennsylvania some years ago.

NU. 1807 , VOL. 70$\urcorner$
Among recent appointments to professorships in American colleges announced in Science are the following:-Prof. C. Baskerville, of the University of North Carolina, to be professor of chemistry in the College of the City of New York. At Cornell University, Mr. D. S. Kimball to be Sibley professor of mechanic arts, in charge of the Sibley shops. Dr. R. Burton-Opitz to be adjunct professor of physiology in Columbia University, with a seat in the faculty of pure science. At the University of Nebraska, inr. G. E. Condra to be professor of geology, and $\mathrm{Mr}$. H. S. Evans to be an adjunct professor of electrical engineering.

IN the thirtieth general assembly of Iowa, it is stated by Science, an appropriation of 10,0ool. was made for erecting either the first of a new series of engineering buildings or the wing of a single large engineering hall at the State University at lowa City. An additional appropriation was made for constructing a dam in the Iowa River which will yield on the average more than three hundred horse-power. This power will be used for lighting and ventilating the university buildings, besides supplying power to the various engineering shops and laboratories. An additional roool. was appropriated for the better equipment of the bacteriological laboratory. Ground will at once be broken for a new museum building to cost about $25,000 l$. The present natural science building, completed in 1885 at a cost of $9000 l$., will be moved bodily to a new site to make room for the proposed structure. The total income of the university for the next biennium will exceed $192,000 l$, about one-third of which must be used for building.

THE Education Committee of the Essex County Council has decided to continue, during the course of the present summer, the Saturday afternoon demonstrations on field botany and other branches of nature-study which have proved highly successful in previous years. Two rambles will be held each Saturday during the remainder of June and throughout July. While these demonstrations are organised exclusively for school teachers, they are not intended only for those who have already studied botany any teacher is eligible who takes an interest in general natural history. The same committee has decided to hold a holiday course in the principles and practice of horticulture at the biological laboratories and garden at Chelmsford for two weeks beginning on August 8 . The object of the holiday course is to assist Essex teachers to gain a knowledge of the gardening operations necessary for the successful working of school gardens. The Essex Education Committee will defray travelling expenses once to and from Chelmsford, and will, in suitable cases, make a special allowance of I2s. $6 d$. per week towards the maintenance of teachers fulfilling the necessary conditions.

THE annual report of the council of the City and Guilds of London Institute for the year 1903 is a gratifying record of continued progress. The high standard of the work at the Central Technical College, at the college in Finsbury, as well as at the other special schools in different parts of London subsidised by the institute, has been well maintained. From the report of the examiners in the department of technology, it would seem that there is a decided improvement in the general character of the work presented, both in the written answers and the practical exercises; the most evident faults in the written parts of the examinations being due to the candidates' imperfect knowledge of the elements of physical science and of drawing, and to their inability to express their ideas in written language. It is certain that no great improvement in the intellectual character of the answers can be looked for until the teaching in elementary schools is made more practical, and further attention is given to training in drawing and scientific method and English composition. The large percentage of failures in all the preliminary examinations is an indication of the unprepared condition of the candidates on commencing their technological instruction. What the examiners in paper manufacture say is applicable to other subjects: "Without a previous attainment to a fair standard of mental training it is impossible either that a student can do justice to the technology of the subject, or have a ready habit of reducing his knowledge to expression." 